University of the Pacific

Scholarly Commons

College of the Pacific Faculty Articles

All Faculty Scholarship

Summer 9-1-2012

\title{
Child Sacrifice in Egyptian Monastic Culture: from Familial Renunciation to Jephthah's Lost Daughter
}

Caroline T. Schroeder

University of the Pacific, cschroeder@pacific.edu

Follow this and additional works at: https://scholarlycommons.pacific.edu/cop-facarticles

Part of the History of Religion Commons, and the Religious Thought, Theology and Philosophy of Religion Commons

\section{Recommended Citation}

Schroeder, C. T. (2012). Child Sacrifice in Egyptian Monastic Culture: from Familial Renunciation to Jephthah's Lost Daughter. Journal of Early Christian Studies, 20(2), 269-302.

https://scholarlycommons.pacific.edu/cop-facarticles/99 


\section{Child Sacrifice in Egyptian Monastic Culture: \\ From Familial Renunciation to Jephthab's Lost Daughter}

\section{CAROLINE T. SCHROEDER}

The Apophthegmata Patrum tells the story of a man who, wishing to join a monastery, reenacts Abraham's sacrifice of Isaac by proceeding to throw his son in the Nile River on the command of the monastic father. Like Isaac, the boy is spared. This account of extreme familial renunciation in the service of the ascetic life is not the only account of a child killing or attempted killing in monastic literature. Nor does the biblical prefigurement of ascetic renunciation exhaust these narratives' significance. This essay examines accounts of child killings in Egyptian monastic culture through the lens of various textual and visual sources: the Greek Apophthegmata Patrum, paintings of the sacrifice of Jephthah's daughter and the averted sacrifice of Isaac at the monasteries of Saint Antony on the Red Sea and Saint Catherine at Sinai, and exegesis of the same biblical narratives in the writings of the Egyptian monk Shenoute and other ascetic authors. What we will see is that powerful moments or rituals of transition and transformation accompany these stories. Thus the textual and visual representations of these killings or attempted killings are theologically, politically, and even socially generative. They reaffirm priestly authority and theological orthodoxy in the monasteries at the same time as they invite male monks to identify with both male and female exemplars. As these paintings and texts reveal, child sacrifice in monastic culture represented not merely an ascetic injunction to abandon family, but, perhaps more radically, an ascetic reproduction of monastic community and genealogy.

I thank David Frankfurter, Maria Doerfler, Elizabeth Bolman, William Harmless, Samuel Rubenson, and Gawdat Gabra for their comments and assistance with this article, as well as several audiences who heard previous versions of the piece. I am also grateful to the editors and the anonymous reviewers at JECS whose advice strengthened the article tremendously. Thanks to the Sinai Archive at the University of Michigan and the American Research Center in Egypt for providing the images. Finally, this essay would not have been possible without generous support from the 
Violence loomed large in the lives, imaginations, and imagined lives of late antique persons on the path to adulthood. Augustine's beatings for failing to learn in school, ${ }^{1}$ John Chrysostom's advice against using corporal punishment, ${ }^{2}$ and Gregory of Nyssa's nocturnal beating by the forty martyrs ${ }^{3}$ all testify to the pervasiveness of such violence. The same is true of the life, imagination, and imagined life of the child in early Egyptian monastic culture.

Children were indeed present in Egyptian monasteries from the fourth century onward. ${ }^{4}$ Despite an impulse in some monastic literature to paint an idealized portrait of a celibate, prayerful life, in which children and all other reminders of a prior life are pushed aside, children make themselves known. They materialize in a number of scenes in the Greek Apophthegmata Patrum, or Sayings of the Desert Fathers. Demons possess children. Demons appear in the guise of children. Lay Christians bring their ill, paralytic, and deformed children to monks for healing. Male monks struggle to renounce and forget their biological children. Yet others bring their children into the ascetic life with them. Despite a variety of representations of children, most of these young people share a common experience: trauma. They undergo trauma from acts of violence, violence narrowly averted, self-inflicted deformities, disease, and demonic possession.

The Greek Apophthegmata Patrum even contains accounts of child killings and attempted killings. In one saying in the alphabetical collection, a man who seeks to join a monastery in Upper Egypt is commanded to throw his son in the river as a requirement of admission:

One of the inhabitants of the Thebaid came to see Abba Sisoes one day because he wanted to become a monk. The old man asked him if he had any relations in the world. He replied, "I have a son." The old man said, "Go and throw him into the river and then you will become a monk." As he went to throw him in, the old man sent a brother in haste to prevent him. The brother said, "Stop, what are you doing?" But the other said

American Academy of Religion, the Graves Award in the Humanities, and the University of the Pacific.

1. Augustine, Conf. 1.14-15, 23 (ed. James J. O’Donnell, Confessions, vol. 1 [Oxford: Clarendon Press, 1992], 8, 11-12; trans. Henry Chadwick, Confessions [Oxford: Oxford University Press, 1991], 11, 17).

2. Blake Leyerle, “Appealing to Children," JECS 5 (1997): 243-70, at 265-66.

3. Vasiliki M. Limberis, Architects of Piety: The Cappadocian Fathers and the Cult of the Martyrs (New York: Oxford University Press, 2011), 65.

4. Caroline T. Schroeder, "Children in Early Egyptian Monasticism," in Children in Late Ancient Christianity, ed. Cornelia B. Horn and Robert R. Phenix, Studien und Texte zu Antike und Christentum 58 (Tübingen: Mohr Siebeck, 2009), 317-38. 
to him, "The abba told me to throw him in." So the brother said, "But afterwards he said do not throw him in." So he left his son and went to find the old man and he became a monk, tested by obedience. ${ }^{5}$

Although Abraham and Isaac are never mentioned by name, this morality tale is clearly modeled on the biblical account of the sacrifice of Isaac in Genesis 22. This biblical scene seems to have resonated with monastic writers and audiences. Similar retellings of the sacrifice of Isaac within a monastic milieu also appear in the Greek anonymous collection of the Apophthegmata and the Latin version known as the Verba seniorum. ${ }^{6}$ John Cassian, who practiced asceticism in Egypt and wrote two books for monks in Gaul, also included in his works two accounts of monks and their sons, which were modeled on Abraham and Isaac story. ${ }^{7}$ Even within late antique and medieval Egyptian monastic culture, depictions of child killings and attempted killings extend beyond the Apophthegmata, and they are not all ascetic retellings of Genesis 22. This essay examines accounts of child killings in Egyptian monastic textual and visual culture (aside from those of child martyrs) through an analysis of the Greek Apophthegmata, paintings of the sacrifice of Jephthah's daughter and the averted sacrifice of Isaac at the monasteries of Saint Antony on the Red Sea and Saint Catherine at Sinai, and exegesis of the same biblical narratives in the writings of the Egyptian monk Shenoute as well as more broadly among late antique ascetic authors. ${ }^{8}$ The art and diverse ascetic texts point to a monastic culture in which violence or attempted violence conveys meaning beyond the ascetic injunction to abandon family.

These child killings or attempted killings are expressed in conjunction with powerful moments or rituals of transition and transformation,

5. Apophth. patr. Sisoes 10 (PG 65:391-407; trans. Benedicta Ward, The Sayings of the Desert Fathers: The Alphabetical Collection [Kalamazoo, MI: Cistercian, 1975], 214).

6. See the discussion of Anonymous Series 295 below. Vit. patr. 14.8 (in the chapter on obedience) is nearly identical to Apophth. patr. Sisoes 10 (PL 73:949; trans. Benedicta Ward, The Desert Fathers: Sayings of the Early Christian Monks [London: Penguin Books, 2003], 143).

7. An analysis of Cassian lies beyond the scope of this article. See Cassian, Inst. coen. 4.27.1-4.28.1 (CSEL 17:65-67; trans. Boniface Ramsey, The Institutes, ACW 58 [Mahwah, NJ: Newman Press, 2000], 92-93); Cassian, Coll. 2.7 (CSEL 13:46; trans. Boniface Ramsey, The Conferences, ACW 57 [Mahwah, NJ: Newman Press, 1997], 89).

8. The essay does not include treatments of child martyrs, since martyrologies express a different aspect of culture and piety than the representations of violent acts analyzed here. All of these depictions of child killings or attempted killings involve as the perpetrators figures ultimately reckoned as pious or faithful in Christian tradition. 
such as the initiation into a monastery, the performance of sacramental duties, or a conversion from heterodoxy to orthodoxy. Additionally, they typically contain sacrificial elements. As such, these visual and textual streams combine to create a monastic culture in which child sacrifice is an undercurrent. Yet, the motif of child killing and child sacrifice is not simply renunciatory, repressive, or destructive-something that brackets off aspects of life and culture (namely, children and family), which are no longer accessible to monks. Child killings ironically prove to be a rather fruitful literary theme. In mimetic readings of the texts and art, monks are invited to identify with a parent willing to kill their child for God, a girl whose sexual purity is offered to God, a biblical patriarch whose life was saved by God, and an orthodox theology equating liturgical bread and wine with Jesus' actual body and blood, all in the process of forging a multigenerational community of holy men. The narration of child killings and attempted killings is theologically, politically, and even socially generative, producing theologies, ideologies, and genealogies of Egyptian monasticism.

\section{BIBLICAL SACRIFICE IN ART AND APOPHTHEGMS}

Two significant artistic representations of child sacrifice exist in monasteries in Egypt, the Greek Orthodox Saint Catherine's Monastery in Sinai and the Coptic Monastery of Saint Antony at the Red Sea. Their sanctuaries display paintings of the two most iconic moments of child sacrifice in biblical literature: the averted sacrifice of Isaac in the book of Genesis and the completed sacrifice of Jephthah's daughter from the book of Judges. At Saint Catherine's, two seventh-century encaustic paintings (one of each sacrifice) stand near the bema of the great church. The portraits frame the altar, hanging on twin marble pilasters, with Abraham on the left and Jephthah on the right (figures 1 and 2). The Abraham painting has sustained some damage from rubbing. The Jephthah painting is very damaged, since an icon of St. Catherine had covered it until 1960. The marble pilaster is blocked by St. Catherine's tomb, making it difficult to see or photograph the image today. Originally, it would have been visible from the nave. ${ }^{9}$ The renovations honoring St. Catherine date to 1715 . At Saint Antony's, a thirteenth-century wall painting depicting both events is likewise placed in a prominent location over the altar (figure 3). These

9. Kurt Weitzmann, "The Jephthah Panel in the Bema of the Church of St. Catherine's Monastery on Mount Sinai,” DOP 18 (1964): 341-52, at 342-44. 


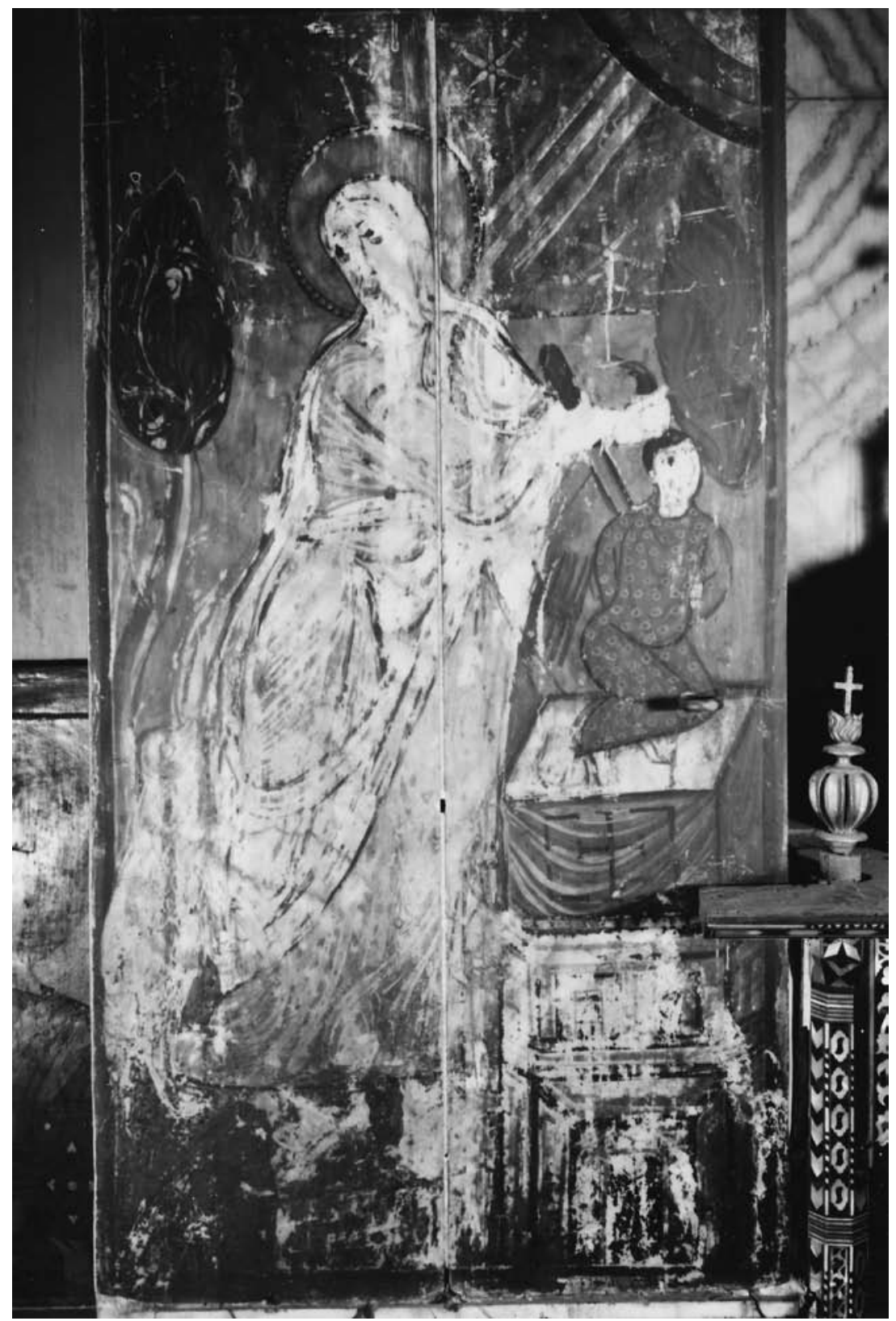

Figure 1. The Sacrifice of Isaac, Saint Catherine's Monastery. Encaustic icon on marble revetment. Reproduced through the courtesy of the MichiganPrinceton-Alexandria Expedition to Mount Sinai. 


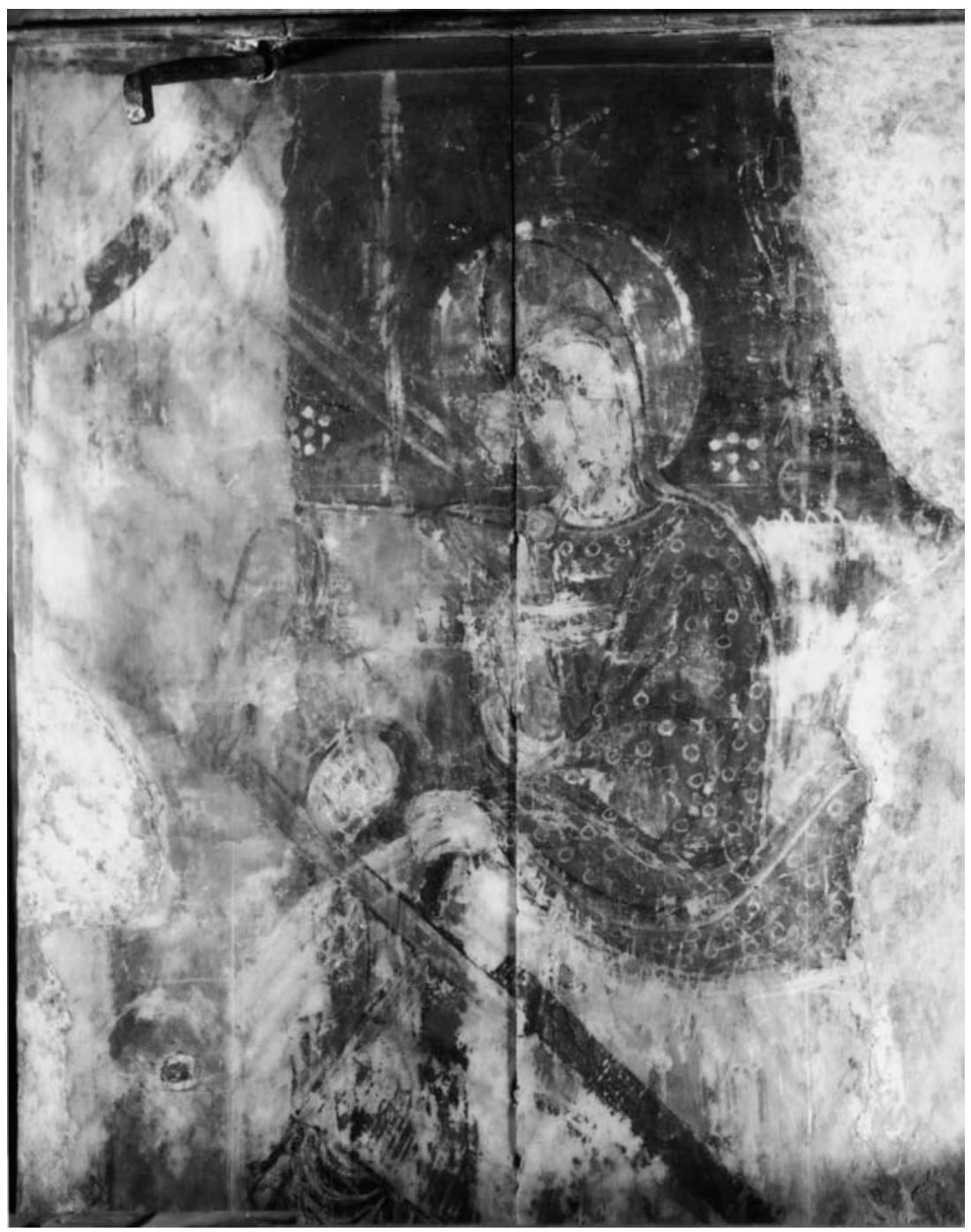

Figure 2. Jephthah and His Daughter, Saint Catherine's Monastery. Encaustic icon on marble revetment. Reproduced through the courtesy of the MichiganPrinceton-Alexandria Expedition to Mount Sinai.

Figure 3. (facing page) The Sacrifices of Isaac and Jephthah's Daughter, Monastery of Saint Antony on the Red Sea. Photograph by Patrick Godeau. Reproduced through the courtesy of the American Research Center in Egypt. 


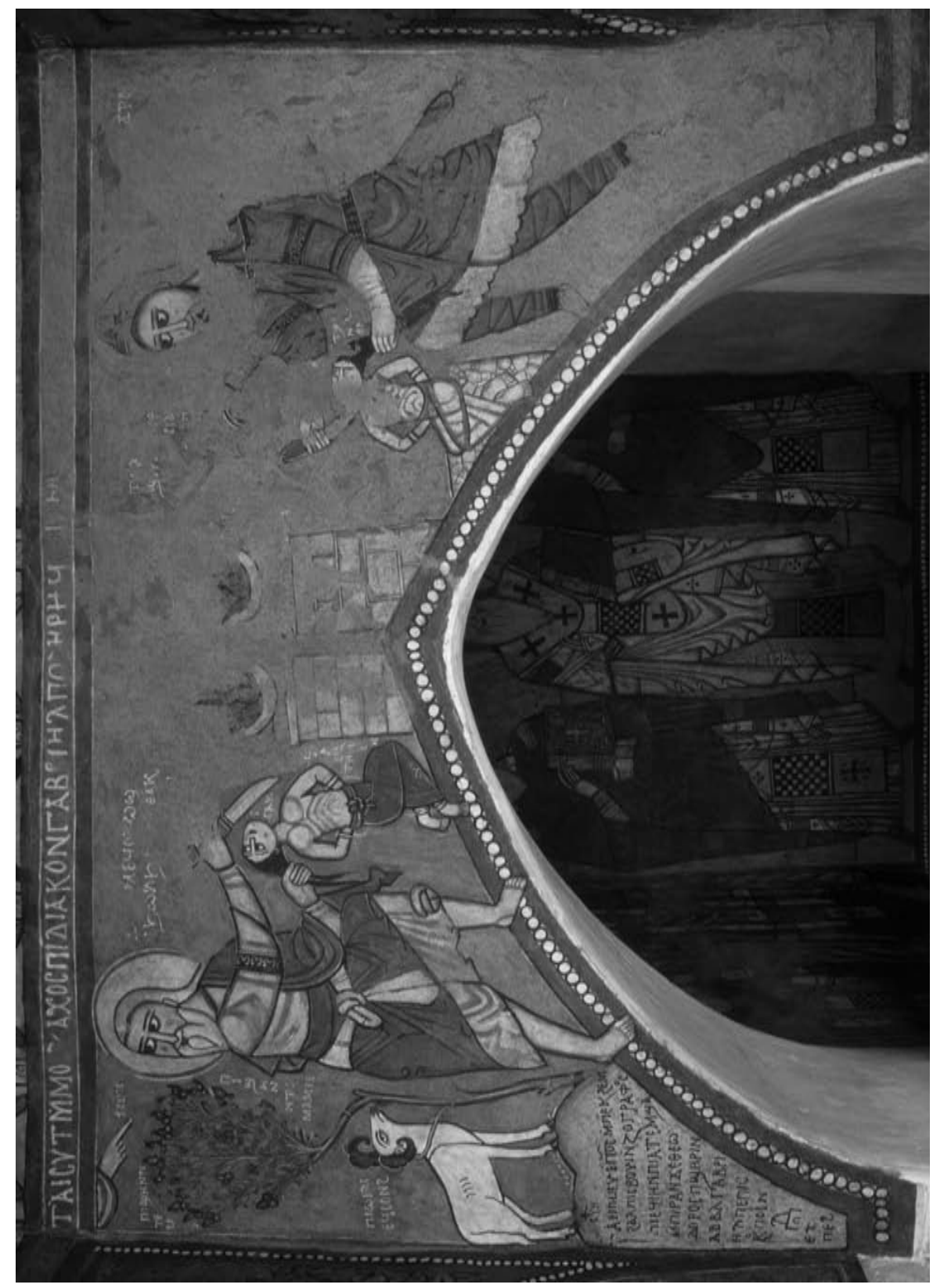


images traditionally have been interpreted as visual representations of biblical, typological prefigurements of Jesus' sacrifice. Positioned at the altar, where the priest would perform the ritual reenactment of Christ's sacrifice through the administration of the Eucharist, the parental figures express the biblical roots of the priest's function and the divine origins and sanctification of the sacrament. ${ }^{10}$

At St. Antony's, in particular, the paintings hang in a circumscribed space; the sanctuary is bounded by wooden screens to protect the holiness of the altar. In this period, the sanctuary screen was typically understood to symbolize the veil of the tabernacle. It protected the priest from the nave and seeing potentially "dangerous" sights (such as women or sinners), which could damage his own sanctity while performing the prayers and sacraments. ${ }^{11}$ At this church, the painting's first audience would indeed be a priestly one. The art, however, is positioned high enough on the wall so that a person standing in the sanctuary can partially see it over the current wooden screens dividing the sanctuary from the nave. At least some of the painting would likely have been visible in the thirteenth century as well. ${ }^{12}$ Assuredly monks who lived in the monastery would have known of its presence, even if they stood in parts of the nave that did not afford a view. The images carried a particular resonance for the monastic audience in this church: as Elizabeth S. Bolman has noted in her study of St. Antony's sanctuary, the paintings evoke the ascetic's vow to offer his or her life as a sacrifice to God. ${ }^{13}$

10. Weitzmann, "Jephthah Panel," 341-52; Paul van Moorsel, "Jephthah? or, an Iconographical Discussion Continued," in Mélanges offerts à Jean Vercoutter, ed. Paul van Moorsel (Paris: Editions recherche sur les civilisations, 1985), 273-78; Elizabeth S. Bolman, “Theodore, 'The Writer of Life,' and the Program of 1232/1233,” in Monastic Visions: Wall Paintings in the Monastery of St. Antony at the Red Sea, ed. Elizabeth S. Bolman and Patrick Godeau (New Haven, CT: Yale University Press, 2002), 37-76, at 66; see also the description of the paintings at St. Antony's in Gertrud J. M. van Loon, The Gate of Heaven: Wall Paintings with Old Testament Scenes in the Altar Room and the Hurrus of Coptic Churches (Leiden: Nederlands HistorischArchaeologisch Instituut te Instanbul, 1999), 91-98, 154-58.

11. Elizabeth S. Bolman, "Veiling Sanctity in Christian Egypt: Visual and Spatial Solutions," in Thresholds of the Sacred: Architectural, Art Historical, Liturgical, and Theological Perspectives on Religious Screens, East and West, ed. Sharon E. J. Gerstel, DOS (Washington, DC: Dumbarton Oaks and Harvard University Press, 2006), 73-104, esp. 95-97, 104. On the power of vision, and the ability of a viewed object to affect the viewer, see Georgia Frank, The Memory of the Eyes: Pilgrims to Living Saints in Christian Late Antiquity, The Transformation of the Classical Heritage 30 (Berkeley, CA: University of California Press, 2000), 122-26.

12. The original screens are no longer extant. On screening and protective elements in the art before the altar at St. Antony's, see Bolman, "Veiling Sanctity," 101.

13. Bolman, “Theodore, 'The Writer of Life,"” 66. 
The paintings at St. Antony's and St. Catherine's express a multiplicity of meanings and should be revisited in light of Egyptian monastic literature, particularly the Apophthegmata Patrum, which contains striking vignettes of child killings and attempted killings, at times modeled on the biblical story of a father and his child. Art in monastic settings functioned as objects of mimetic veneration. While participating in the church liturgies, or even while praying before an image in a monk's own cell, the ascetic experienced a ritual transformation in which he or she identified with the figure represented in the art. As Bolman has argued in her study of the interplay between monastic literature (especially the Apophthegmata Patrum) and monastic art, the monk "achieves the imitation of these exemplars through acting like them, through hearing or reading about them, and through learning to see them." In viewing the images of spiritual beings within their sacred space, the monks "learned to become like them, and indeed to become them." ${ }^{14}$ The paintings of Isaac and Jephthah's daughter in conjunction with monastic literature raise provocative questions about the person(s) with whom the viewer and reader are to identify: Abraham, Isaac, Jephthah, or his daughter?

The religious communities at St. Antony's and St. Catherine's would have been well-versed in the Apophthegmata Patrum. The text was copied and translated widely in the late antique and medieval eras. St. Catherine's library currently houses Greek, Syriac, Georgian, Old Church Slavonic, and Arabic manuscripts of the Apophthegmata Patrum dating from the eighth to seventeenth centuries. ${ }^{15}$ Although the Monastery of St. Antony was looted in the fifteenth century, making the library's precise contents unknown, it housed a thriving and influential monastic population and a significant manuscript collection in the medieval era. The monks certainly would have studied the Apophthegmata. ${ }^{16}$ Also at St. Antony's, monks

14. Bolman, "Joining the Community of Saints: Monastic Paintings and Ascetic Practice in Early Christian Egypt," in Shaping Community: The Art and Archaeology of Monasticism. Papers from a Symposium Held at the Frederick R. Weisman Museum, University of Minnesota, March 10-12, ed. Sheila McNally, British Archaeological Reports International Series 941 (Oxford: Archaeopress, 2001), 46, 44.

15. See Kenneth Willis Clark, Checklist of Manuscripts in St. Catherine's Monastery, Mount Sinai (Washington, DC: Library of Congress, 1952), 7, 15, 18, 19, 36; Murād Kāmil, Catalogue of All Manuscripts in the Monastery of St. Catharine on Mount Sinai (Wiesbaden: Harrassowitz, 1970), 28-36, 59, 76-90, 148.

16. On manuscripts, the library, and the looting of the monastery, see Gawdat Gabra, "Perspectives on the Monastery of St. Antony: Medieval and Later Inhabitants and Vistors," in Monastic Visions, ed. Bolman, 173-84, at 173-74, and Coptic Monasteries: Egypt's Monastic Art and Architecture (Cairo and New York: The American University in Cairo Press, 2002), 73. Scholarship on the translations and 
profiled in the Apophthegmata and other monastic literature line the nave of the church. ${ }^{17}$ Although the master artist, Theodore, did not originate from Egypt, but rather Syria or Palestine, other painters on his team were Egyptians, and he was familiar with the literary traditions about Egyptian monasticism. As Bolman, has shown, the iconography in the old church of St. Antony's is steeped with references to events, characters, and ascetic teachings from the Apophthegmata..$^{18}$ A later painter at the nearby monastery of St. Paul seems to have consulted with the Apophthegmata as he created his art. ${ }^{19}$

In addition, the image of Jephthah's daughter cannot be dismissed as a mere import of a foreign artist but must be understood within the context of Egyptian monasticism as well as eastern Mediterranean culture more

versions of the Apophthegmata in languages other than Greek is minimal. However, we can say with certainty that the monks at the monasteries of Saint Antony and Shenoute knew the Apophthegmata, just as the monks at St. Catherine's did. The texts were translated widely in late antiquity and the Byzantine era. The copy of the Sahidic Coptic translation used by most scholars originates from a monastic library, namely, Shenoute's White Monastery (see Marius Chaîne, Le manuscrit de la version Copte en dialecte Sahidique des" Apophthegmata Patrum" [Cairo: L'Institut français d'archéologie orientale, 1960]). Although this copy does not contain all the sayings examined here, many folios are missing, and of course one codex cannot be taken as representative of all Sahidic manuscripts of the Apophthegmata circulating in late antiquity. The sayings examined here circulated widely throughout the late antique Mediterranean, appearing variously in Greek versions as well as in Latin, Armenian, Syriac, Ethiopic, and Sahidic; see Lucien Regnault, Les sentences des pères du desert, troisième recueil et tables (Sablé-sur-Sarthe: Solesmes, 1976), 208-11, 238-39, 26263. Samuel Rubenson is currently conducting research on the Arabic versions of the Apophthegmata. Today the library in the Monastery of St. Antony contains many manuscripts of Arabic versions of the Apophthegmata. These manuscripts date from the fourteenth through eighteenth centuries, and some of them are likely translations from Coptic and Greek versions. Some of these translations were probably done in the monastery during the twelfth and thirteenth centuries. The size and characteristics of this collection indicate that the monks of St. Antony's read the Apophthegmata collectively and individually during the history of the monastery (Samuel Rubenson, personal correspondence, May 18-19, 2011). Finally, the monastic saints on the walls of the old church at St. Antony's do not all draw from a later liturgical text, the Synaxarion; one figure (Sisoes) is featured in the Apophthegmata but not the Synaxarion; see Birger A. Pearson, "The Coptic Inscriptions in the Church of St. Antony," in Monastic Visions, ed. Bolman, 222, 268 n. 36.

17. Bolman, "Theodore, 'The Writer of Life,"” 48-54.

18. Bolman, "Theodore, "The Writer of Life," " esp. 37.

19. William Lyster, "Reviving a Lost Tradition: The Eighteenth Century Paintings in the Cave Church, Context and Iconography," in The Cave Church of Paul the Hermit at the Monastery of St. Paul, Egypt, ed. William Lyster (New Haven, CT: Yale University Press and American Research Center in Egypt, 2008), 209-31, at 231. 
broadly. Religious politics and cultural innovation crossed geographical boundaries during this period, such that Egyptian and Syrio-Palestinian artistic trends influenced each other. We know that an influential Coptic family during the thirteenth century had houses in both Damascus and Cairo. ${ }^{20}$ Images and motifs in the wall paintings at St. Antony's and the neighboring St. Paul's Monastery share elements with Byzantine art from elsewhere in the Mediterranean. ${ }^{21}$ At both St. Antony's and St. Catherine's, the theological matrix in which these paintings were created was infused with a rich literary tradition in which the stories of Isaac and Jephthah's daughter were told, explained, exegeted, justified, asceticized, and even reconfigured for a monastic community. Moreover, this literary culture included accounts of child sacrifice or killings that extended beyond retellings of Genesis and Judges. In four accounts in the Greek Apophthegmata Patrum in which monks engage in violence against children, these acts are presented as occurring during sacrificial events. The alphabetical and anonymous collections contain three explicit stories of child sacrifice or sacrifice averted and one story of the murder of a pregnant woman in which the death of the fetus is counted as a separate crime apart from the death of the woman. In three of the stories, the monks hearing and reading the Apophthegmata are implicitly invited to identify with the person conducting the killing, since that person becomes a monk like themselves.

All four of these sayings are sacrificial by nature; that is, they contain a constellation of elements Kathryn McClymond has identified as endemic to ritual sacrifice cross-culturally. ${ }^{22} \mathrm{McClymond}$ theorizes sacrifice as a matrix of ritual elements rather than as a statically defined phenomenon. Not all sacrificial events include all elements, but various combinations of the following seven criteria appear in sacrificial activities: 1) the "selection" of "the appropriate sacrificial substance"; 2 ) "association" of the event with a deity or deities; 3 ) "identification" of the offering or ritual with a "patron who benefits from the sacrifice"; 4) "killing," or the "intentional execution of the offering"; 5) "heating" the offering with fire; 6) "apportionment" of the offering to "specific ritual participants"; 7) "consumption" of the

20. Stephen J. Davis, Coptic Christology in Practice: Incarnation and Divine Participation in Late Antique and Medieval Egypt, Oxford Early Christian Studies (Oxford: Oxford University Press, 2008), 253.

21. Bolman, "Theodore's Program in Context: Egypt and the Mediterranean Region," in Monastic Visions, ed. Bolman, 91-102, at 99-102; Bolman, "The Medieval Paintings in the Cave Church, Phase One: Continuity," in Cave Church of Paul the Hermit, ed. Lyster, 163-77, at 168, 171-72.

22. Kathryn McClymond, Beyond Sacred Violence: A Comparative Study of Sacrifice (Baltimore, MD: Johns Hopkins University Press, 2008). 
offering. ${ }^{23}$ As McClymond argues, these seven elements are "basic activities that generate sacrificial events when combined," and thus she moves scholars of religion beyond the question of whether an event is or is not sacrifice and urges us to ask instead whether it is more or less sacrificial in nature. ${ }^{24}$ The sayings each contain at least four of McClymond's seven sacrificial elements, albeit variously configured.

The art and apophthegms exemplify another theoretical conceptualization of the role of sacrificial events: the gift-exchange, especially between the devotee and the divinity, in which blood sacrifice is particularly transformative. ${ }^{25}$ The sayings and paintings all depict sacrificial events in which bloodshed occurs or is anticipated during a gift exchange between a person and his deity or his sanctified community. Through these exchanges, sacred relationships and communities are forged or reinforced.

Earliest asceticism, even communal asceticism, was commonly understood as a sacrificial act, namely a sacrifice of family and offspring (among other things). For example, Shenoute, the leader of a monastic community of several thousand men and women, praised those who left behind their sons and daughters "because of their love for God and his blessed son." 26 Representations of the ascetic life as a complete rejection of traditional family, however, are somewhat exaggerated; at Shenoute's monastery and elsewhere, siblings or parents and children joined monasteries together, requiring the new monks and their institutions to renegotiate the terms of their familial bonds, subordinating their traditional familial attachments

23. McClymond, Beyond Sacred Violence, 29-33.

24. McClymond, Beyond Sacred Violence, 25, 27.

25. See Marcel Mauss, The Gift: Forms and Functions of Exchange in Archaic Societies, trans. W. D. Halls (London: Routledge, 1990); Walter Burkert, Homo Necans: The Anthropology of Ancient Greek Sacrificial Ritual and Myth (Berkeley, CA: University of California Press, 1986); Burkert, "Sacrifice, Offerings, and Votives: Introduction," in Religions of the Ancient World: A Guide, ed. Sarah Iles Johnston (Cambridge, MA: Harvard University Press, 2004), 325-26. The literature on sacrifice as a religious category is too vast to summarize here. The theories of Burkert and Mauss (among others) have come under increasing scrutiny in recent years. McClymond for one critiques the centrality of blood and violence in Mauss's and Burkert's theories of sacrifice (44-64, esp. 44-46). McClymond raises legitimate concerns; nevertheless, blood and violence (real or anticipated) are central to the art and apophthegms in this study.

26. Shenoute, Canon 7, XU 100-101 (ed. Émile Amélineau, Oeuvres de Schenoudi: Texte copte et traduction française, 2 vols. [Paris: Ernest Leroux, 1907-1914], 2:153). For an extensive treatment of ascetic interpretations of the Bible in Greek and Latin writers, in particular, see Elizabeth A. Clark, Reading Renunciation: Asceticism and Scripture in Early Christianity (Princeton, NJ: Princeton University Press, 1999), 177-203. According to Clark, interpretations of Luke 14.25-27 were especially foundational in ascetic arguments for the abandonment of family (198). 
to the ties forged by their new ascetic "families" - their brothers, sisters, mothers, and fathers in Christ. ${ }^{27}$ Frequently monks maintained kinship networks in the face of Shenoute's admonitions otherwise. Nonetheless, the ascetic ideal of familial renunciation remained, and narratives of child sacrifice in the sayings reinforce this ideal. The concurrent evidence for biological kin maintaining their familial networks exposes the tensions inherent in daily monastic life.

The story of Abraham's averted sacrifice of Isaac in Genesis serves as the dramatic and obvious model for the ascetic sacrifice of family. In the saying quoted at the opening of this essay (Sisoes 10 of the Alphabetical collection), the aspiring monk's actions mirror the biblical patriarch's. ${ }^{28}$ Like Abraham, the father's commitment to God is tested by a command to kill his son, and like Isaac, the son is saved by a last-minute intervention on his behalf. Despite his physical survival, the child nonetheless serves as a sacrificial object; though he lives, the father leaves him behind without even an afterthought as a sign of his devotion only to God in pursuit of his ascetic vocation. The story provides opportunity for a doubled-mimesis; the reader (or hearer) imitates both the esteemed monk of the saying and the patriarch Abraham (whom the monk of the story in turn has imitated) in adopting the ascetic life.

In a parallel story of ascetic child sacrifice in the anonymous collection, one monk does follow through with an attempted murder of his biological son. This man is a more established ascetic, who left his three children behind to join a monastery three years earlier. The father becomes depressed over his separation from his offspring, and after speaking to his abbot about his sadness, the abbot orders the monk to find the children and bring them to the monastery. He discovers that two have died and returns with the third, a son. He seeks out his abbot, whom he finds in the monastery's bakery. The abbot covers the child with kisses and asks the monk, "Do you love him?" and then, "Do you love him very much?" When the monk replies affirmatively, the abbot commands him to throw the son in the bakery's furnace "so that it burns him." The monk casts his child into the furnace, at which point it "immediately became like dew, full of freshness." ${ }^{29}$ The transformation of the oven to dew may mean that

27. Rebecca Krawiec, Shenoute and the Women of the White Monastery (New York: Oxford University Press, 2002), 161-74.

28. Apophth. Patr. Sisoes 10 (PG 65:391-407; trans. Ward, 214).

29. Apophth. Patr. Anon. 295 in F. Nau, "Histoires des solitaires Égyptiens," Revue de l'orient Chrétien 14 (1909): 378; trans. Benedicta Ward, The Wisdom of the Desert Fathers: Apophthegmata Patrum from the Anonymous Series (Fairacres, UK: SLG Press \& Convent of the Incarnation, 1975), 47 (numbered saying \#162). 
the child survives. It may also imply that the child has been conveyed to heaven, and thus that his earthly life, at least, has been extinguished. Dew has a biblical association with heaven and divine benevolence. The "dew of heaven" is a treasured gift of God in Genesis. According to Numbers, manna would fall from heaven "when the dew fell on the camp" of the Israelites. Dew signifies God's blessing in Psalm 133. In the book of Daniel, heavenly dew "bathes" Nebuchadnezzar during his seven years of exile, indicating that despite suffering and tribulations, the king is saved, sanctified, and eventually made right with God; his exile from "human society" is simultaneously a punishment and a divine embrace. ${ }^{30}$ Whether the child in the apophthegm is to be understood as living or miraculously assumed to heaven, this oblique reference effectively ends his lifeline, for the saying makes no further mention of the boy or his prospects. Instead the apophthegm ends with a commentary on the actions of the biological father: "Through this act, he received glory like the patriarch Abraham."

These two ascetic retellings of the sacrifice of Isaac illustrate a motif that runs throughout the Apophthegmata Patrum: the symbolic representation of children as sacrificial objects. Both men receive commands to sacrifice their children from their institution's leadership as part of a ritual of initiation. In the first story, the sacrifice functions as a primary ritual of initiation; he must kill the child in order to prove his faith and join the community. In the second story, the sacrifice functions as a ritual of initiation as well, in that the monk only becomes a true and tested monk once he has enacted the sacrifice. That the abbot commanded the monk to seek out his children indicates that this is an institutionally authorized act, designed to test the man's obedience to monastic authority, with the abba as patron. ${ }^{31}$ The monk only affirms and fully embraces his monastic identity once he reenacts Abraham's sacrifice of Isaac. Though he has lived at the monastery for three years, his initiation is complete only upon the enactment of the sacrifice.

Remarkably, in both of these sayings, the fate of the child remains unstated. This shared narrative element signifies two important themes in the stories: the primacy of the parent as the ritual agent in the sacrifice and the extinguishing of the child as the sacrificial object. In Genesis, Abra-

30. Gen 27.28; Num 11.9; Ps 133.3; Dan 4.15, 4.23-25, 4.33, 5.21. These passages represent just a sample of the biblical associations of dew with God and heaven. I thank an anonymous reader for the reference to Daniel.

31. The Verba Seniorum apophthegm on this theme appears in the chapter on obedience, thus reinforcing the abba's role as patron as well as the institutional elements of the story. 
ham continued to parent Isaac, and Isaac himself went on to become no minor figure in biblical tradition. Isaac's very survival leads to the establishment of the covenant between God and Abraham, Isaac, and Isaac's descendants. The story of the sacrifice of Isaac is rather the story of the survival of Isaac and the engendering of an entire people. But the saying's storyline follows the father, and the father's dedication to God. It also narrates a story about community, but about the father's community and his acceptance into that community through the excision of his children from his life. The ascetic life is an act of mimesis, modeling oneself on the dedication of the biblical parent willing to kill his child for God. The parent's future depends upon the narratological (if not literal) death of the child. As the parents' lifelines flourish, the children's narrative threads die. Levitical notions of sacrifice depend upon the immolation or destruction of the sacrificial offerings. As Caroline Walker Bynum has noted, Christian interpretations of this type of biblical sacrifice and theorizings about Christ's death often express anxiety about this fundamental element of sacrifice inherited from the Jewish Scriptures. According to Bynum in her study of blood piety, the essential element of Christ's sacrifice is sometimes interpreted to be his death (the extinguishing of his life), but often emphasis turns to interpreting the crucifixion as an offering from which the violent act of killing has been expunged; the offering up of his blood provides an example. Christ's blood becomes an oblation to God, a gift strangely dissociated from the act that enabled its existence. ${ }^{32}$ The children of these monks do not die, but they are extinguished as gift-offerings that evoke the blood of physical sacrifice but are strangely dissociated from physical death. They are extinguished from the monks' lives, from the monks' community, and from the monks' identities.

The extinguishing, destruction, or "killing" of a sacrificial object need not be bloody or violent, as McClymond has persuasively argued; sacrificial substances are "manipulated" in a variety of violent and nonviolent ways. What the religious theorist should attend to is what the "killing" or manipulation of the sacrificial object enables. ${ }^{33}$ The stories of child sacrifice in the Apophthegmata participate in sacrificial discourses in which offerings subject to immolation and destruction generate power or facilitate relationships. David Frankfurter has also called upon scholars to question our tendencies to label all religiously imbued deaths or bloodlettings

32. Caroline Walker Bynum, Wonderful Blood: Theology and Practice in Late Medieval Northern Germany and Beyond (Philadelphia, PA: University of Pennsylvania Press, 2007), 234.

33. McClymond, Beyond Sacred Violence, 44-46, 64. 
"sacrifices." ${ }^{34}$ Curiously, the child sacrifices in the Apophthegmata are sacrifices, but not bloody slaughters. They are informed by several of McClymond's sacrificial criteria: selection, association, identification, and killing (here, symbolic killings). They express late antique Christian ambivalence about the legacy of blood sacrifice in the theology and practice inherited and adapted by the tradition. Even though these children are not killed, they function narratologically, symbolically, and mimetically as ritual blood sacrifices. They serve as offerings to God, which only carry transformative meaning when extinguished.

In this way, the accounts in the Apophthegmata recall the story of another biblical child sacrifice-one also depicted at Saint Antony's and Saint Catherine's, and one whose life is literally extinguished: that of Jephthah's daughter. In the book of Judges, Jephthah vows to sacrifice the first living thing that walks through his door to greet him upon his return if God will provide him with victory in battle. Tragically, the first person who welcomes him home is his daughter, his only child. Jephthah, with his daughter's consent, fulfills his vow and enacts the sacrifice (Judg 11.30-40). The monks' stories mirror Jephthah's in two ways, as sacrifices of destruction and as sacrifices enacting a gift-exchange through the offering. Like Jephthah, the monks in the Apophthegmata offer their children, and like Jephthah's daughter, the children's role in the narrative ends with their sacrifice. Though neither of the monks in the Apophthegmata takes a monastic vow during the course of the narrative, these sacrificial acts are part of their ritual fulfillment of their obligation to God through a monastic initiation. Some monastic communities in Egypt required a vow or established a ritual of initiation. Monks at Shenoute's monastery swore an oath upon entrance. ${ }^{35}$ The most famous coenobitic community, the Pachomian monasteries, did not seem to have ritualized an oath of initiation, but other ascetic sources mention the taking of vows or the donning of the monastic habit as inherent to the ascetic life. ${ }^{36}$ The ascetics' prom-

34. Frankfurter has encouraged researchers of late antique sacrifice to dislodge the act of slaughter from its central locus in our understanding of ancient sacrifice, and thus to question the primacy of animal and blood sacrifice in our accounts of late antique religious ritual. The child sacrifices in the Apophthegmata are sacrifices but not slaughters, and express the late antique Christian's own ambivalence about the role of blood sacrifice in its legacy in the theology and practice it has inherited and adapted. See David Frankfurter, "Egyptian Religion and the Problem of the Category 'Sacrifice," in Ancient Mediterranean Sacrifice: Images, Acts, Meanings, ed. Jennifer Knust and Zsuzsanna Varhelyi (New York: Oxford University Press, 2011), 75-93.

35. Krawiec, Shenoute and the Women, 20-21; Schroeder, Monastic Bodies, 4.

36. Athanasius, Ep. virg. 1.33 (trans. David Brakke, Athanasius and Asceticism [Baltimore, MD: Johns Hopkins University Press, 1998], 285). Cassian, Coll. 9, as cited by 
ise to dedicate their lives to God mirrors Jephthah's oath. Their offering of their children functions as a gift-offering that fulfills their obligation to God, the gift required to fully enter the community of living saints that is the monastery, just as the sacrifice performed by Jephthah repays his obligation to God for his victory in battle. Several scholars of the Hebrew Bible have persuasively argued that human sacrifice, even child-sacrifice, was normative (even if rare) in parts of the ancient Near East, and that passages in the Christian Old Testament (including Judges 11) provide evidence that child sacrifice even to the God of the Israelites was acceptable. ${ }^{37} \mathrm{I}$ do not propose that these literary rituals of initiation recollect historically enacted rituals of monastic initiation in which living children were killed or almost killed. The elimination of the child from the monk's family constitutes a death or a loss, one that is simultaneously metaphorical and anchored in the material realities and consequences of sacrificial events. Egyptian monks did not kill children as part of an initiation ritual, but ceremonies of initiation involved renouncing a former life through ritual acts, such as donning the monastic garb or taking monastic oaths. The ritual act of donning the habit or reciting the vow transformed the monk, in no small part because it involved a renunciation of the man's former life, a life that would have included living with and maintaining constant communication with his biological family.

Harmless, Desert Christians: An Introduction to the Literature of Early Monasticism (New York: Oxford University Press, 2004), 393. I am grateful to William Harmless for these citations. On oaths and donning the habit, see also Rebecca Krawiec, "'Garments of Salvation': Representations of Monastic Clothing in Late Antiquity," JECS 17 (2009): 125-50; Ewa Wipszycka, Moines et communautés monastiques en Égypte (IVe-VIII ${ }^{e}$ siècles), Journal of Juristic Papyrology Supplements XI (Warsaw: Warsaw University, 2009), 365-81.

37. The scholarship on this issue is extensive; for recent treatments see "Sacrifice, Offerings, and Votives: Israel," in Religions of the Ancient World, ed. Johnston, 333-36; Alice Logan, "Rehabilitating Jephthah,” JBL 128 (2009): 665-85. On child sacrifice in the Hebrew Bible and the evidence for the practice as normative in the ancient Near East and, under certain conditions, in ancient Israelite religion, see Logan, "Rehabilitating Jephthah"; Karin Finsterbusch, "The First-Born between Sacrifice and Redemption in the Hebrew Bible," in Human Sacrifice in Jewish and Christian Tradition, ed. Karin Finsterbusch, Armin Lange, and Diethard Römheld, and in association with Lance Lazar, Numen Book Series: Studies in the History of Religions 112 (Leiden: Brill, 2007), 87-108; Armin Lange, “They Burn Their Sons and Daughters-That Was No Command of Mine' (Jer 7:31): Child Sacrifice in the Hebrew Bible and in the Deuteronomistic Jeremiah Redaction," in Human Sacrifice, ed. Finsterbusch et al., 109-32; Michaela Bauks, "The Theological Implications of Child Sacrifice in and beyond the Biblical Context in Relation to Genesis 22 and Judges 11," in Human Sacrifice, ed. Finsterbusch et al., 65-86. 
McClymond argues that sacrificial elements are visible, ritual categories even in moments that are "not traditional sacrifice" - episodes or traditions that have "translated" sacrifice into "symbolic or internalized forms." 38 The renunciation of family praised by Shenoute and enacted in initiation rituals or vows certainly qualifies as such an "internalized" sacrifice, in which the gifts or sacrificial objects are the monk's family and secular life path. Looking at the early Christian context, David Biale has shown that early Christian authors renarrate, reinterpret, and reframe biblical stories of blood sacrifice. In such rewritings, the materiality of blood is not wholly washed away by its symbolic interpretations. Blood, the shedding of blood, the sharing of blood, and the spreading of blood signified community. Christian sacrificial discourse spiritualized the practice of blood sacrifice while it continued to traffic in ancient blood symbolisms. Likewise, Egyptian monastic culture did not completely detach from the bodily and bloody acts depicted in the Apophthegmata and the paintings at St. Antony's and St. Catherine's. ${ }^{39}$ The narratives in the Apophthegmata about fathers sacrificing their children mimic Abraham and Isaac (a child sacrifice averted, a young boy saved), but elements of these narratives evoke Jephthah and his daughter as well. As I will explain below, standing near the monastic altars at the moment of her death, she signifies a more complete blood sacrifice. In a parallel sacrificial act, the gift-offering of the monks is complete, for they have given up real biological children or the potential to have biological children in order to pursue lives of holiness.

\section{PRIESTS, PENANCE, AND INFANTICIDE}

Monastic literature's accounts of violence against children extend beyond ascetic rewritings of these biblical dramas. Two accounts in the Apophthegmata present the butchering of babies as turning points in "edifying" narratives about adult monks. In one saying, three monks debate whether the Eucharist is truly the flesh and blood of Christ. One is quite skepti-

38. McClymond, Beyond Sacred Violence, 154-55, and also the discussion of the spiritualization of Gen 22 in 157-59.

39. David Biale, Blood and Belief: The Circulation of a Symbol between Jews and Christians (Berkeley, CA: University of California Press, 2008), 45. Biale takes interpretations of the covenant of blood in Exodus 24 as his starting point (not Genesis 22 or Judges 11), but his analysis extends more broadly to the role of sacrificial blood in community formation. He here follows and develops Guy Stroumsa's characterization of late antique Judaism and Christianity as "sacrificial religions without blood sacrifices." Biale writes, "Each of them 'spiritualized' sacrifice in distinctive ways but also developed physical practices that substituted for sacrifice." 
cal, asserting the bread and wine are merely symbols. The next Sunday, the monks attend church services together. As the priest places the bread on the table, there also appears a small child. As the priest prepares the Eucharist, an angel pours the child's blood into a chalice, chops the child into little bits, and offers the once-skeptical monk a "morsel of bloody flesh." Afraid, the man shouts aloud that he believes the Eucharist indeed to be the body and blood of Christ. ${ }^{40}$ Thus the flesh and blood of the child prove the ontological status of the bread and wine in the church's ritual sacrifice. This story seems to be directed against Origenism, Melitians, or other "heresies" which asserted that the Eucharist was only a "symbol" or a "type" of Christ's flesh and blood, rather than an actual ritual manifestation of his physical body. ${ }^{41}$ In yet another anecdote, Apa Apollo, before becoming a monk, was moved by the devil to tear open a pregnant woman and rip the fetus from her body, killing them both. ${ }^{42} \mathrm{He}$ is struck with remorse and joins a monastery to live a life of prayer.

The moral freight both of these butchered children carry is sacrificial. The eucharistic child quite obviously represents Jesus Christ and his sacrifice for the repentance of sins. The physicality of the butchered child testifies to the physicality of both Jesus' original sacrifice as well as the eucharistic bread and wine.

This textual image of child sacrifice fits well with eucharistic interpretations of the art at Saint Catherine's and Saint Antony's. And it provides a reason for the specific inclusion of Jephthah's daughter in the iconographic programs, even though her death is a story rarely discussed in early Christian literature and even more rarely depicted in art. The paintings at both monasteries portray Jephthah's daughter as a blood sacrifice whose ritual is in the process of completion. The two depictions share some iconographic similarities, such as the positioning of the figures. They are not identical, however; Jephthah's clothing, for example, differs. ${ }^{43}$ Despite damage to the painting at St. Catherine's, Jephthah is partially visible and can be seen in the process of cutting his daughter's throat (figure 2). Likewise, at St Antony's, the dagger is in the girl's neck (figure 4). In both, Jephthah stands behind his daughter and pulls her head back by grasping her hair and tugging downward. These paintings contrast with their twins, the

40. Apophth. Patr. Daniel 7 (PG 65:156-60; trans. Ward, 53-54).

41. On the Eucharist in the Origenist controversy, see Elizabeth A. Clark, The Origenist Controversy: The Cultural Construction of an Early Christian Debate (Princeton, NJ: Princeton University Press, 1992), 64-66.

42. Apophth. Patr. Apollo 2 (PG 65:133-36; trans. Ward, 32).

43. van Loon, The Gate of Heaven, 155. 


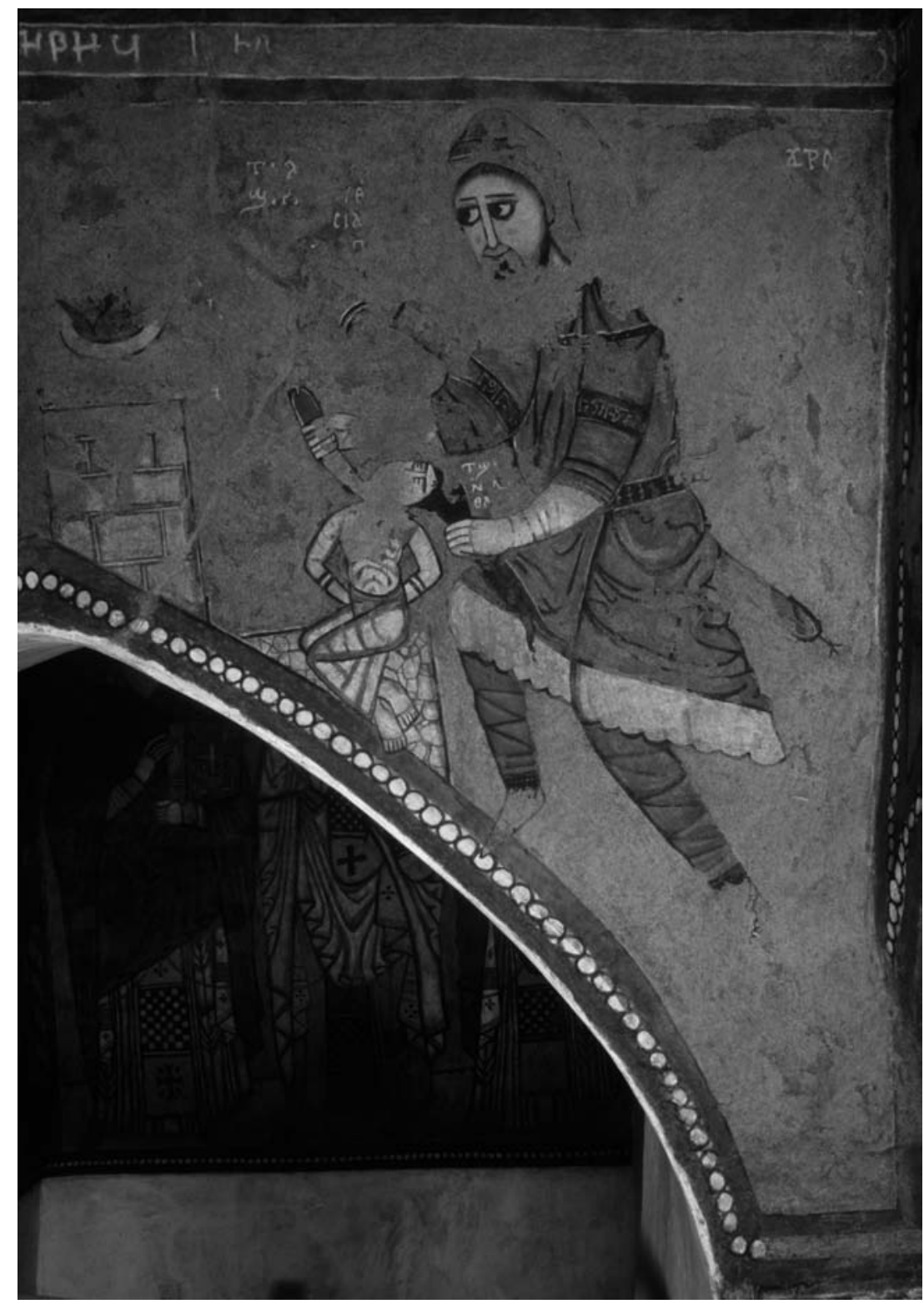

Figure 4. The Sacrifice of Jephthah's Daughter, Monastery of Saint Antony on the Red Sea. Photograph by Patrick Godeau. Reproduced through the courtesy of the American Research Center in Egypt. 
sacrifice of Isaac, in which Abraham's blade is poised above the child's neck (figures 1 and 5). Whereas Isaac is a sacrifice averted, Jephthah's daughter is a more complete prefigurement of Christ's death (which is celebrated in the Eucharist). Her blood is shed, and she is killed. Just as in the graphic imagery in the Apophthegmata, the girl's real physical death reminds the viewer of the physicality of Christ's death and the equation of the Eucharist with his sacrificial body. While a lamb hovers in the background of both of the Isaac panels, reminding the viewers of the coming of Christ as a lamb of God, Jephthah's daughter prefigures God's completed sacrifice of his own flesh and blood, his own child. A couple of medieval Coptic texts also viewed her typologically. She foreshadowed Christ's crucifixion, although her blood redeemed her alone and not all of humanity. ${ }^{44}$

The fetus in the story of Apa Apollo also plays a role in a sacrificial drama. Although the incident is narrated as a tremendous sin motivated by the devil, it is nonetheless the sin that propels Apollo to convert to the ascetic life. While couched as an act of murder, the fetus's death is a necessary event in the narrative. On a narratological level, the unborn child's future, and that of its mother, are sacrificed so that Apollo might come to live a "life of God." This saying recounts a sort of inverted sacrificial event, in which two are slaughtered in a multi-layered "gift" exchange. In this case, something is taken by Apollo (their lives), which he then has an obligation to repay. He offers his life (a life spent in atonement), for which he then receives something sacred in return (his monastic community and relationship with God). The monk, the woman, and the fetus are all sacrificial substances manipulated by the narrator and Apollo in turn. As interpreters of the text, we should attend to the dead victims but also, in the words of McClymond, to what the killings enable: sacred relationships, expressed in Apollo's admission to the monastic community. Homiletical parallels in contemporaneous Christian exegesis of Judges 11 confirm that this saying can be understood as inherently sacrificial. In early Christian hermeneutics, Jephthah's daughter's death often serves a similar moral purpose as the fetus's death. In the words of Jerome, the girl dies so that "he who had improvidently made a vow, should learn his error by the death of his daughter." 45 Although wrong, her death enables Jephthah's

44. van Loon, The Gate of Heaven, 157.

45. Jerome, Iov. 1.5, 23 (PL 23:226, 252-54; trans. NPNF² 6:349, 363). Jerome approvingly paraphrases an interpretation of Judg 11.30-31, which he attributes to "the Hebrews." He takes Jovinian to task for praising Jephthah (for his "fidelity" to God) more than the daughter. In an attempt to draw suspicion to Jovinian's own dedication to the faith, Jerome claims that even Jewish commentators condemn Jephthah, and that for his own part, he praises not virgins of the world but virgins who dedicate their virginity to Christ. I thank Elizabeth A. Clark for this reference. 


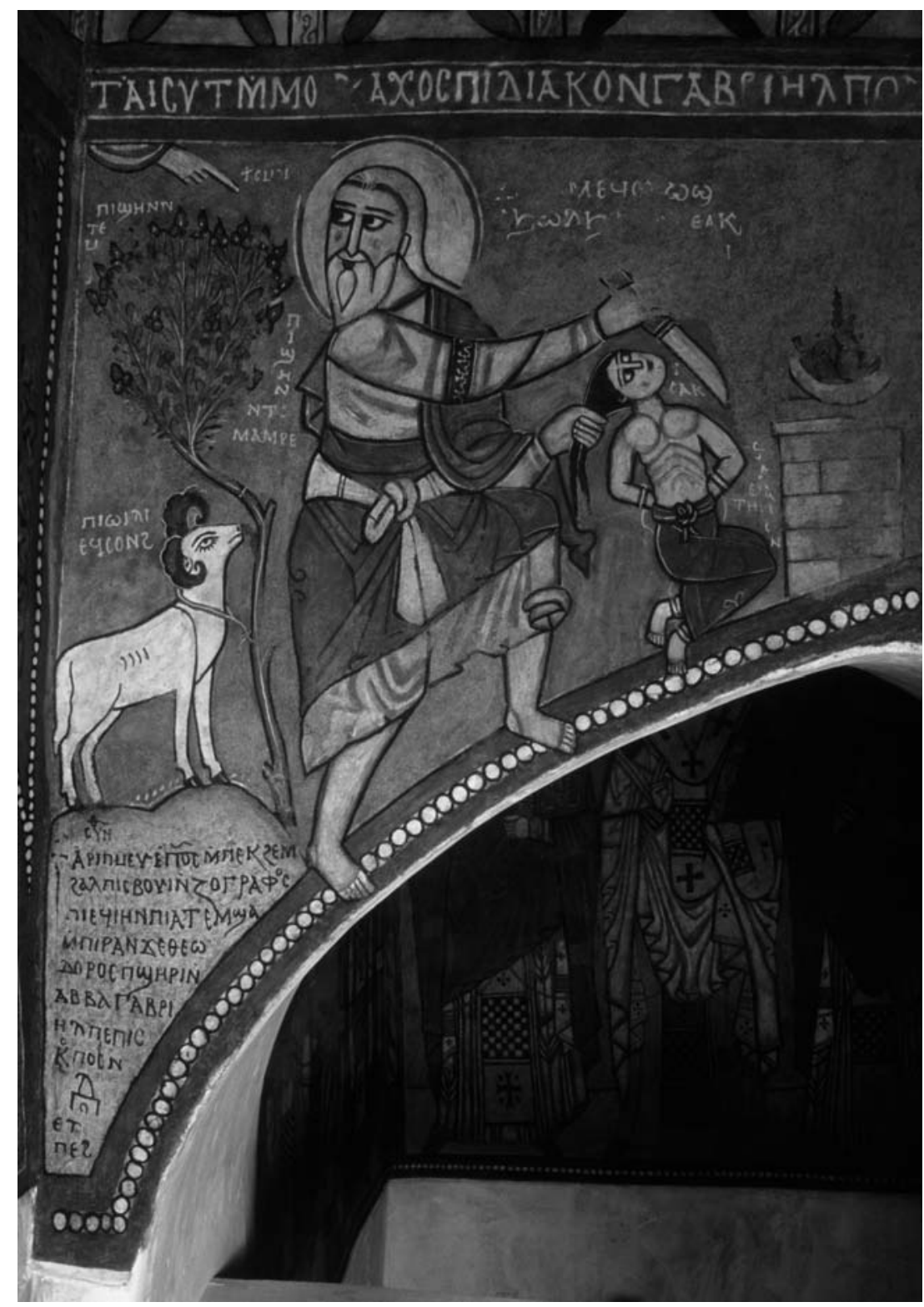

Figure 5. The Sacrifices of Isaac, Monastery of Saint Antony on the Red Sea. Photograph by Patrick Godeau. Reproduced through the courtesy of the American Research Center in Egypt. 
spiritual growth. In a similar vein, the pregnant woman's death enables Apollo's spiritual growth. As I will discuss later in the essay, in much of early Christian biblical interpretation, the death of Jephthah's daughter performs this moral function. The girl's death is viewed as a tragic necessity for the benefit of others.

That stories of child sacrifice and child killings are featured in texts as popular and authoritative as the Apophthegmata Patrum is somewhat surprising given the accusations of cannibalism, infanticide, and other similar horrors, which pagans levied against Christians in the pre-Constantinian era. As David Frankfurter has noted, Coptic texts like the Panegyric of Macarius of Tkow revive charges of human sacrifice, but enlist them against the people in Egypt who continue to worship traditional deities. In other words, there are other accounts of child sacrifice in Egyptian Christian literature, but they represent a reversal of the ancient pagan polemic against Christians: Christians demeaned their opponents with the very accusations of human sacrifice they themselves had once faced. Frankfurter argues that in a text like the Panegyric such "details of human sacrifice . . . derive from polemical and literary topo $i$ of subhuman religion." ${ }^{46}$ Infanticide, in particular, is a form of a "widespread myth of the Other in antiquity." 47 Building on Frankfurter's analysis, the Isaac story in the Christian tradition can serve as a story of Christian superiority: unlike the religions of the "Other," the Christian God does not demand human sacrifice to venerate him. However, there is some tension between the accounts I have examined from the Apophthegmata and the polemical tropes of infanticide and sacrifice discussed by Frankfurter. In the Apophthegmata, the children are sacrificial, and some of them are killed, in narratives of initiation into the ascetic life or conversion to orthodox eucharistic theology.

\section{CHILD SACRIFICE REJECTED AND REDEEMED IN EARLY ASCETIC EXEGESIS}

The images at the monasteries of St. Catherine and St. Antony were created in a religious culture in which these motifs of child sacrifice existed in literature. Both the art and texts held authoritative positions and possessed

46. David Frankfurter, "Illuminating the Cult of Kothos: The Panegyric on Macarius and Local Religion in Fifth-Century Egypt," in The World of Egyptian Christianity: Language, Literature, and Social Context, Essays in Honor of David W. Johnson, ed. James E. Goehring and Janet A. Timbie, CUA Studies in Early Christianity (Washington, DC: The Catholic University of America Press, 2007), 176-88, at 182.

47. Frankfurter, "Illuminating the Cult of Kothos," 187. 
mimetic qualities for their communities. In the stories and images of child sacrifice, with whom is the reading or listening monk to identify, who is the monk to imitate? How is this identification and mimesis expressed and understood? And what does it mean for a monk to identify either with the children or the parents, the dead child or the spared child? Finally, what would images and stories of child sacrifice mean for communities in which children were living amongst adult monks? Monastic texts suggest that sacrificial imagery was profoundly multivalent. Ascetic and monastic writings, including those of the Egyptian monk Shenoute, revisit the stories of the sacrifice of Jephthah's daughter and the averted sacrifice of Isaac in order to impart ascetic wisdom to their readers. Isaac and Jephthah's daughter served to reinforce church doctrine about the Eucharist as well as the ascetic obligation to renounce family and procreation.

In none of the texts of the Apophthegmata, however, is the monk asked to identify with the sacrificial child. Rather, the sacrifice is part of a ritual (either the Eucharist or an explicit or implicit ritual of initiation) in which the monk functions as the ritual subject and agent. Yet, elements of the paintings — especially of Jephthah's daughter's story-do indeed suggest a monastic identification with the object of sacrifice. In later Jewish and Christian interpretation, the power of the death of Jephthah's daughter lay in no small part in her virginity. The Jewish author Pseudo-Philo wrote a lament for the girl, in which she does not express grief over her impending death, but proclaims her own willing decision to offer herself as a sacrifice; thus she becomes the model for holiness and righteousness. ${ }^{48}$ As a virgin, she is a pure sacrifice, and she faces a death, which comes before she can live a life that has fulfilled its potential.

In early Christian literature, as Kurt Weitzmann notes, most "church fathers" interpret Jephthah's act as one of foolishness; his vow serves as a lesson to future believers never to make such a ridiculous oath. ${ }^{49}$ The earliest Christian reference to Jephthah comes, of course, in the book of Hebrews, where he is listed alongside other military leaders and righteous men (such as David); no mention is made of his daughter (11.32). Ascetic authors of the patristic age, however, did not avoid speaking of her and in

48. Cynthia Baker, "Pseudo-Philo and the Transformation of Jephthah's Daughter," in Anti-Covenant: Counter-Reading Women's Lives in the Hebrew Bible, ed. Mieke Bal (Sheffield: Almond Press, 1989), 195-209.

49. See the surveys of patristic, early medieval, and early Byzantine commentary in Weitzmann, "Jephthah Panel," 350-52; John Lee Thompson, Writing the Wrongs: Women of the Old Testament among Biblical Commentators from Philo through the Reformation, Oxford Studies in Historical Theology (New York: Oxford University Press, 2001), 100-138. 
fact found much to say about the vow that led to the very military victories honored in Hebrews. Ambrose of Milan exclaims, "Far better to have made no such promise, than to fulfill the promise with the murder of his own daughter!" 50 Although Ambrose balks at openly criticizing Jephthah, he in effect pillories the father as a poor example for Christian officials who seek to dedicate their lives to God: "I cannot censure a man who felt it necessary to honour the vow he had made, but the necessity was nevertheless a tragic one.... It is better not to make a vow at all than to make a vow which the one to whom you are making the promise has no desire should be paid." ${ }^{51}$ An ascetic himself, Ambrose finds redemption and a pious exemplar in the girl's actions. Like Pseudo-Philo, he praises her for choosing to die "of her own strength of will" and "free determination." In enabling her father to fulfill his oath, she turns "an impious accident" into a "pious sacrifice." 52

She is characterized as a martyr by some commentators, even a prefigurement of Christ in her bodily sacrifice. A hymn of Ephrem the Syrian links her blood to the blood of Christ's crucifixion and the blood of a virgin's hymen:

Jephthah's daughter willed to die to fulfill her father's vow.

Do not annul by your eyes the vows of virginity your mouth has vowed.

Jephthah poured out his daughter's blood,

but your Bridegroom shed His blood for love of you.

Therefore that Only-Begotten blood bought

That blood by which your gate is sealed. ${ }^{53}$

Ephrem, an ascetic himself, identifies with and expands upon a detail in the original passage from Judges: Jephthah's daughter's virginal status. In the tradition of Greek sacrificial narratives, the girl's value is measured by her sexuality purity, and part of what she and her father offer to God is the sacrifice of her future as bride and mother. For Ephrem, this virginity is the "pearl" the girl cherishes until death. ${ }^{54}$ Likewise, the girl's virginal

50. Ambrose, Off. 1.255 (ed. and trans. Ivor J. Davidson, Ambrose: De Officiis, Oxford Early Christian Studies, 2 vols. [Oxford: Oxford University Press, 2002], $1: 266-67)$.

51. Ambrose, Off. 3.12.78-79 (Davidson, 1:400-403).

52. Ambrose, Off. 3.12.81 (Davidson, 1:404-5).

53. Ephrem, Hymns on Virginity 2.11 (CSCO 223, Scriptores Syri 94:7; trans. Kathleen E. McVey, Ephrem the Syrian: Hymns, CWS [Mahwah, NJ: Paulist Press, 1989], 269). See also Weitzmann, "Jephthah Panel," 351-52. Weitzmann comments on the blood-sacrifice element to Ephraim's hymn, but not on Ephrem's attention to virginity.

54. Ephrem, Hymns on Virginity 2.10 (CSCO 223, Scriptores Syri 94:7; trans. McVey, 268). As McVey observes, Ephrem changes the story in his asceticization of 
status would resonate with monks gazing at the paintings, and it would invite the monks to identify with her not just because they, like Jephthah's daughter, offer their lives to God, but also because they, like Jephthah's daughter, offer their sexual purity to God.

Similarly, Latin and Greek ascetic writers in the fourth century praise Jephthah's daughter as a model for female asceticism and Jephthah himself as an exemplar for men or women who renounce family. ${ }^{55}$ The depiction of women other than Mary in early monastic church art is rare, and exceedingly rare in Egypt; no female saints (aside from the virgin mother) appear in the church of Saint Antony's walls, and at Saint Paul's Monastery on the Red Sea (near Saint Antony's) three female martyrs and one woman monk (Marina) appear in the program of saints. ${ }^{56}$ (Marina is also a crossdressing saint, known for wearing men's clothing so as not to appear to be a woman.) So although infrequent, female holy women do appear as objects of male monastic mimesis. Thus the sacrificial images in the paintings of Genesis 22 and Judges 11 invite predominantly male monks to identify their own ascetic dedication with a female figure as well as a male.

Ephrem is not the only ascetic patristic author who fails to denounce Jephthah unequivocally. Jerome, for one, equivocates. He condemns Jephthah in Against Jovinian (as cited above), but twenty-five years later, in his Commentary on Jeremiah, he reverses himself and praises the father's intentions (though not his execution of them). ${ }^{57}$ Although evaluations of Jephthah are more often critical than praising, I posit that there is a curious effect to juxtaposing the two patriarchs (Abraham and Jephthah). A rereading of John Thompson's survey of biblical interpretation of Judges 11 alongside additional late antique commentary demonstrates that many cite Jephthah as an example of what not to do, and as a reminder that men

it (268 n. 30). In Judges, the daughter mourns her virginity for two months, whereas for Ephrem, her virginity is a consolation.

55. Thompson, Writing the Wrongs, 114-15, who even goes so far as to argue that in the epitaphs on his mother, Nonna, Gregory of Nazianzus identifies himself and his mother with Isaac and Jephthah's daughter; he is the child his mother dedicated to Christ and she is the woman who offered up her life to Christ. Gregory's parallel of Nonna and Jephthah's daughter is clear, but I find the argument that Gregory himself identified with the girl to be a stretch. (See Gregory of Nazianzus, epit. 94 [PG 38:58]. Also numbered as epig. 51 in W. R. Paton, ed. and trans., The Greek Anthology, with an English Translation, LCL 67, 68, 84, 85, 86 [London: William Heinemann; New York: G. P. Putnam's Sons, 1917], here 68:422-23).

56. Lyster, "Reviving a Lost Tradition," in Cave Church of Paul the Hermit, ed. Lyster, 223, 225, 226, 346-47 n. 113.

57. Jerome, Iov. 1.5, 23 (discussed above n. 45); see also the treatment of Jerome in Thompson, Writing the Wrongs, 121-24. 
should not attempt to emulate Abraham. Yet the combination of Abraham and Jephthah is provocative given the sacrificial imagery in the monastic texts. Early Christian authors reveal their awareness of the optics of the Judges story: when linking Abraham with Jephthah, they tacitly admit that it looks bad for a patriarch of the tradition to commit child sacrifice. Procopius of Gaza takes pains to explain that Jephthah's act cannot be compared to the events of Genesis $22 .{ }^{58}$ Ambrosiaster insists Jephthah was not a righteous man, as Abraham was. ${ }^{59}$ In the City of God, Augustine counts both fathers among men who kill (or intend to kill) but cannot be deemed guilty of murder (or attempted murder). Abraham justly deserves praise for his deeds, Augustine writes; of Jephthah, he remarks, "And it may rightly be asked whether it was also by God's command that Jephthah slew his daughter." ${ }^{60}$ In his more extensive treatment of Judges 11 in Questions on the Heptateuch he concedes that Jephthah was well-meaning (albeit misguided) but resolutely maintains that he should not be admired; God provides Jephthah's story as warning to all those who might imitate Abraham. ${ }^{61}$ (Abraham's test, apparently, was unique, not to be repeated.) John Chrysostom takes the interpretive approach of loving the sinner but hating the sin; Jephthah's faithfulness did not excuse his improvident promise. He functions as the vow to end all such vows. Had God intervened to save the girl, Chrysostom argues, even more people would make these oaths, leading to countless murdered children. Like Augustine, Chrysostom reads Jephthah's tragedy as God's warning to subsequent believers not to seek to follow in Abraham's footsteps. Uniquely, however, Chrysostom reads these two stories with opposite outcomes as having the same purpose: God's intervention on Isaac's behalf in Genesis and the mourning over Jephthah's daughter in Judges both prove that God does not "delight in such sacrifices." ${ }^{2}$ A monk from Sinai, writing in the

58. Procopius of Gaza, Gen.-Jud. 11.30, as quoted in Thompson, Writing the Wrongs, 132.

59. Ambrosiaster, Qu. test. 43, as quoted in Thompson, Writing the Wrongs, 124.

60. Augustine, Civ. 1.21 (CCSL 47:23; trans. R. W. Dyson, The City of God against the Pagans, Cambridge Texts in the History of Political Thought [Cambridge: Cambridge University Press, 1998], 33-34).

61. Augustine, Hept. 7.49 (CCSL 33:358-73). Augustine has complicated views on Jephthah; see the analysis of Hept. in Thompson, Writing the Wrongs, 125-30.

62. John Chrysostom, Stat.14.3 (PG 49:147-48; trans. NPNF 9:434 [numbered as Homily 14.7]). This homily rails against oath-taking in general, during a period of political unrest in Antioch, when residents are making accusations (sometimes false, according to Chrysostom) against fellow Antiochenes to the authorities. The bishop thus uses Jephthah as an example of reckless oath-taking resulting in dire consequences. See also Thompson, Writing the Wrongs, 116-18, for more on Chrysostom. 
same century as the creation of the painting of Jephthah and his daughter, condemns the father's actions and accuses both parent and child of lacking the righteousness of Isaac and Abraham. Yet even he finds a divine reason for her untimely death: she dies "in order to instruct the living and those yet to be." She sacrifices her life so that others may learn the folly of her father's ways. ${ }^{63}$ Despite efforts to distance Abraham and later Christian tradition from Jephthah, we nonetheless find commentators seeking to resolve their differences and prominent paintings pairing the men in important monastic churches. The tendency to refer to Abraham and Isaac when the question of Jephthah arises suggests that the commentators indeed protest too much. ${ }^{64}$ The pairing of the two men in literature and art does not exclusively render Jephthah extreme by comparison. Their continual association both validates Jephthah's act and deploys it for additional theological and symbolic purposes.

To return to the Egyptian context, a handful of late antique and medieval Coptic texts mention Jephthah. One encomium compares him to Abraham and faults him not for offering his daughter as a sacrifice but for lamenting her impending death. Another encomium follows the book of Hebrews and lists him among several saints and righteous men. ${ }^{65}$

One Coptic author invokes Jephthah's daughter as a model for asceticism, alongside Jephthah, Abraham, and Isaac. In a sermon entitled, "I Have Been Reading the Holy Gospels," Shenoute expounds upon the importance of the vow to ascetic life. Written in 431, soon after Shenoute's return from the ecumenical Council at Ephesus, the text contains an extensive treatment of the monastic vow and the clerical vow, particularly the oath of celibacy or virginity. ${ }^{66}$ When addressing monks who break their vows after the fact, Shenoute pairs the concepts of fidelity and sacrifice. He begins by speaking of God's love for humanity and offers Jesus, including his death, as the major sign of God's love. God sacrificed his only son for the sake of humanity, insists Shenoute, and so the least monks and clergy can do is to hold fast to their own vows, which constitute much smaller sacrifices. He singles out not only those men who fail to maintain their

63. Weitzmann, “Jephthah Panel,” 351.

64. Only a few later commentators uncritically blend the story of Jephthah's daughter with that of Isaac, including Peter Chrysologus in the East and Paschius Radbertus in the West (Thompson, Writing the Wrongs, 134, 135).

65. van Loon, The Gate of Heaven, 157.

66. Mark Moussa, “'I Have Been Reading the Holy Gospels' by Shenoute of Atripe (Discourses 8, Work 1): Coptic Text, Translation, and Commentary,” Ph.D. diss. (Catholic University of America, 2010), 1; for more on the historical context and dating of the sermon, see Moussa, “I Have Been Reading the Holy Gospels," 1-8, 13-19. 
celibacy but also men who strive to become monks or clergy with questionable motives. He asks God, "[D]o you discover among us that someone will say, 'I did something for you?' As for him who says, 'I have done a deed for you,' it is for himself that he is actually doing it." Christ's death models Shenoute's ideal of a selfless sacrifice. Jesus' sacrifice leads Shenoute to write of other fathers who sacrificed their children, namely the biblical patriarchs Jephthah and Abraham. The citation is brief, yet powerful:

If some have offered up to you their children as sacrifices, like the great Abraham the patriarch and Jephthah, while others again did not do it for you, it is you who rewarded them with what they had no power ever to obtain. You rewarded all of them here and allowed them to inherit eternal life, these among whom Christ came in the flesh, your only-begotten Son who exists before the ages. It is he whom you sent to the world at the last days, [who] gave himself for our sins and for our impiety, and [who] rose on the third day. ${ }^{67}$

Shenoute quickly pivots back to the topics of Christ's incarnation, sacrifice, and resurrection, but the implication is clear: monks who either renege on their promises, or pledge celibacy with selfish motives compare poorly to the true, selfless sacrifices committed by Abraham and Jephthah, men who both maintained their commitments to God and, according to Shenoute, were willing to carry out a selfless sacrifice.

Shenoute reconfigures even Isaac, the iconic sacrifice-deferred, to signify an actualized ascetic sacrifice. Shenoute identifies Isaac as a model for discipline in which ascetics, in sacrificing themselves to God, are asked to imitate Abraham and his son simultaneously. Paraphrasing Romans, he refers to Isaac as a model sacrifice, which all monks should imitate in their endeavors to purify their bodies through ascetic discipline. Monks should obey God, just as Abraham obeyed without hesitation, so that they, too, may offer themselves as pure sacrifices to God. ${ }^{68}$

Reviewing the vast history of Jewish and Christian commentary on Judges 11, much less Judges 11 and Genesis 22, is beyond the scope of this essay. But focusing on even a selection of ascetic exegetes is illuminating. The combination of ascetic commentary on Judges 11 with the images at Saint Catherine's and Saint Antony's suggest that not only Isaac, not only the Eucharist, but also the story of Jephthah's daughter, with her bloody

67. Shenoute, I Have Been Reading the Holy Gospels 19 (Moussa, "I Have Been Reading the Holy Gospels," 57; trans. Moussa, 151).

68. Shenoute, The Lord Thundered, manuscript GG ff. 27-28 (Amélineau, 2:142; trans. Janet A. Timbie and Jason R. Zaborowski, "Shenoute's Sermon The Lord Thundered: An Introduction and Translation," OrChr 90 [2006]: 91-123, at 107). 
death, lurks behind accounts of child killings and sacrifice in monastic literature. She and Isaac are multivalent symbols in an ancient multimedia culture, referencing renunciation, virginity, martyrdom, obedience, and the Eucharist.

\section{CHILD SACRIFICE, CULTURAL HERITAGE, AND MONASTIC REPRODUCTION}

These sayings are disturbing, for they present children and monks in ways that disrupt conventional mores. Righteous fathers do not throw their sons in rivers or ovens. Grown men do not drink the blood of babies. Holy men do not murder pregnant women. Their power lies in their ability to provoke. Their unsettling natures require contemplation, interpretation, and explanation. Despite their shocking qualities, these sayings are not completely renunciatory in nature. As I have already shown, within their larger literary and artistic monastic context they are theologically generative, in that they produce eucharistic theologies both visually and textually. Moreover, they are socially and politically generative, creating monastic communities through genealogies engendered by ascetic sacrifice rather than biological reproduction.

One of the more provocative aspects of Apollo's crimes is that the death of the fetus haunts him more than his murder of the pregnant woman. His continued penance over the fetus's death raises questions about the cultural value of children as represented in the text. Apollo reportedly spends his life in prayer, becoming convinced that God has forgiven him the sin of murdering the woman, "but for the child's murder, he was in doubt." Another monk who heard his prayers one day told him, "God has forgiven you even the death of the child, but he leaves you in grief because that is good for your soul." Why does the death of a fetus weigh more heavily on Apollo's soul than the death of a woman? One reading might turn to innocence for the explanation: the death of the child represents the death of an innocent, compared to the death of the adult woman. Yet, although the innocence of children has roots in early Christianity, scholars of the history of childhood have argued that the concept of the "innocent childhood" and the accompanying cultural semiotics of children signifying purity and innocence take their strongest hold in modernity. ${ }^{69}$

69. See the historical and historiographical survey in the first three chapters of Colin Heywood, A History of Childhood: Children and Childhood in the West from Medieval to Modern Times (Malden, MA: Wiley-Blackwell, 2001), esp. 4, 20, 33, on the cultural construction of childhood innocence. On innocence and infants in eastern 
Another contextually Roman cultural signification of children privileges the fetus's life over the woman's. For Greco-Roman families, the cultural and symbolic value of children lay in their reference to the future. Children represented the legacy of the family and the society-a legacy of culture, economics, and reputation. To kill a child was to kill the future. For example, legislation about abortion in the Roman world focused not on a moral equivalency between murder and terminating a pregnancy, but on the issue of legacy; women who aborted their children deprived their husbands and their society of its legacy. ${ }^{70}$

Thus the story of Apollo the murderous monk can also be read as a discourse on traditional Greco-Roman family values. Despite being a fetus-killer-perhaps even by being one-Apollo affirms the importance of children in late antiquity, even late antique monastic culture. Although Apollo embarks on the more virtuous life of celibacy and familial renunciation, his tale implicitly reifies the cultural significance of children as society's legacy. Killing the future is a greater sin than killing the past. The dead fetus has dual meanings. Apollo as a literary character exists within a monastic literary collection populated by children who typically experience severe trauma, even attempted murder or death. In this way, the monastic culture appears distinctively anti-child. The fetus, due to Apollo's eternal penance, also speaks to a monastic culture that embraces children as symbols of a society's legacy.

The child killings are also paradoxically productive, rather than renunciatory, when examined as narratives of sacrificial rituals. Anthropologist and religious theorist Nancy Jay has argued that particularly in maledominated cultures, ritual sacrifice is intricately connected with modes of cultural and biological reproduction. "The practice of sacrifice affects family structures, the organized social relations of reproduction within which women bear their children." ${ }^{71}$ Examining the practice of sacrifice in cultures as diverse as ancient Greece and Rome, Hawaii, and West Africa, Jay argues that ritual sacrifice "identif[ies], and maintain[s] through

and later Syriac traditions (in contrast to Greek and Latin patristic views), see Maria Doerfler, "The Infant, the Monk and the Martyr: The Death of Children in Eastern Patristic Thought," Mus 124 (2011): 243-58.

70. Judith Evans Grubbs, Law and Family in Late Antiquity: The Emperor Constantine's Marriage Legislation (Oxford: Oxford University Press, 1995), 96; Grubbs, Women and the Law in the Roman Empire: A Sourcebook on Marriage, Divorce, and Widowhood (London: Routledge, 2002), 202, 311 n. 28.

71. Nancy Jay, Throughout Your Generations Forever: Sacrifice, Religion, and Paternity (Chicago: University of Chicago Press, 1991), xxiv. 
time, not only social structures whose continuity flows through fathers and sons but also other forms of male to male succession that transcend dependence on childbearing women.... [I]t identifies social and religious descent, rather than biological descent," and thus produces genealogies that are "no longer directly dependent on women's reproductive powers for continuity." 72 Ritual sacrifice thus encodes and maintains a genealogy in which women's role in reproducing that society is deemed less relevant than other modes of social and cultural reproduction.

Sacrificial rituals often promote social communion or expiation. In the former, communion sacrifice, members of a community are initiated into the group or their membership in the group is affirmed through participation in a sacrifice. In expiation sacrifice, sin, guilt, pollution, or some other disruptive element is expelled during the ritual. The line between these two forms of sacrifice is not bright; like expiation sacrifices, communion sacrifices are rituals of differentiation-they distinguish members of the enculturated group from outsiders; similarly, expiation sacrifices promote internal cohesion by ridding a person or a group of difference. ${ }^{73}$ Although aspects of Jay's theories remain controversial, the political and social functions of sacrifice are widely acknowledged. ${ }^{74}$ Sacrificial activities, as McClymond summarizes, construct and reinforce communities with distinctive and often politically charged identities: "[S]acrifice is often the arena in which certain people distinguish themselves from others, community versus community, social rank versus social rank, modern religion versus ancient religion." 75 David Biale, in his examination of blood in Judaism and Christianity, also notes that rituals and discourses of blood sacrifice had a significant political dimension, which overtook their theological dimension. In the Hebrew Bible, blood and blood discourse had an

\section{Jay, Throughout Your Generations, 37.}

73. Jay, Throughout Your Generations, 17-20.

74. Jay has received criticism for universalizing specifically western cultural categories and in imposing them on non-western cultures misinterpreting her evidence (see Leslie Goode, “'Creating Descent' after Nancy Jay: A Reappraisal of Sacrifice and Social Reproduction," Method \& Theory in the Study of Religion 21 [2009]: 383-401, as well as the concerns of McClymond, Beyond Sacred Violence, 2, 11-13, 45-46, about narrowing a definition of sacrifice to animal killing, excluding plant and liquid offerings, and focusing analysis on violence in sacrifice [all of which characterize Jay's work]). Since the material examined in this essay is firmly rooted in the western tradition, which is Jay's primary paradigm, and involves acts of violence as well as animal or human sacrifice and killing, her theories are useful for this particular work. Despite their critiques, McClymond and Goode share Jay's concerns for how sacrificial activity leads to community formation and cohesion.

75. McClymond, Beyond Sacred Violence, 3. 
"indexing" function, pointing to one group's sacred authority over some of the wider community's social practices, and even over certain constituencies within that community. As Biale has argued, a key constituency is women: blood discourses in the Hebrew Bible concerning sex, animal slaughter, and criminality index priestly authority over food and over women. ${ }^{76}$ The art at St. Catherine's and St. Antony's, and the accounts of child killings and averted killings in the Apophthegmata christianize and transform some of the discourses of blood found in the Christian Old Testament, but they retain an indexing function. Child killing is authorized in the context of prefiguring or conducting the priestly act of distributing the Eucharist. Child killing is rationalized as a martyrdom, virginal offering, or precursor to monastic conversion. Child killing is also questioned through the mimetic act of identifying with Isaac or Jephthah's daughter.

Jay is especially interested in how sacrificial rituals between men and performed by men establish and perpetuate explicitly patrilineal lines of descent. She writes, "Man born of woman may be destined to die, but man integrated into an 'eternal' social order to that degree transcends mortality." 77 Sacrifice, with its "twofold movement" of "integration and differentiation," or "communion and expiation," in her words,

is beautifully suited for identifying and maintaining patrilineal descent. Sacrifice can expiate, get rid of, the consequences of having been born of woman ... and at the same time integrate the pure and eternal patrilineage. Sacrificially constituted descent, incorporating women's mortal children into an "eternal" (enduring through generations) kin group, in which membership is recognized by participation in sacrificial ritual, not merely by birth, enables a patrilineal group to transcend mortality in the same process in which it transcends birth. ${ }^{78}$

In other words, male ritual experts create male-to-male, patrilineal genealogies through sacrificial rituals of initiation and assimilation. In three of the four sayings examined here, sacrificial child killings and attempted killings occur during or immediately prior to rituals of initiation, in which the monks enter a patrilineal group and differentiate themselves from others. The fourth (the killing of the Christ child) occurs during a ritual of transformation (the Eucharist) in which the monks join the ranks of

76. See the treatment of sacrifice and priestly power in the Hebrew Bible in Biale, Blood and Belief, 13.

77. Jay, Throughout Your Generations, 39.

78. Jay, Throughout Your Generations, 40. As McClymond, Beyond Sacred Violence, 45, notes, Jay's attention to expiation is very Girardian, in that sacrifice rids a community of a perceived problem-namely, women or biological descent. 
Christian orthodoxy. Likewise the art in St. Catherine's and St. Antony's monasteries affirms (male) priestly authority by invoking prefigurements of Christ and the Eucharist as well as the sacred boundary of the celibate male community by depicting the virginal sacrifice of Jephthah's daughter. These textual and visual acts of sacrificial child killings are a socially and culturally generative process, which allow celibate men to regenerate their own social group, one not dependent on biological reproduction but nonetheless one in which fathers beget sons who carry on a social and cultural legacy.

\section{CONCLUSIONS}

The role of sacrifice in constructing an exclusively male, sacred, authoritative community is not unproblematized in the Egyptian monastic material. On the one hand, the saying narrating Apollo's crimes confirms Jay's insights: his murders propel him to join the monastery, where the killing of the woman does not jeopardize his relationship with God and status as monk. On the other hand, the inclusion of Jephthah's daughter simultaneously affirms and troubles the patriarchal paradigm. The girl dies at the hand of a father who lives on as a righteous man in Christian culture. But at the same time, her presence in the monastic churches demonstrates that masculinity cannot subsume into itself all the social contributions and cultural codes provided by women. While the priest may identify with the fathers, the monk may identify with them or with the girl. The texts and paintings contribute to a rich and multifaceted symbolic culture.

In the sayings and art examined here, sacrificial events represent a transformation of sacrificial rituals but do not translate into a simple one-to-one replacement of sacrifice with ascetic renunciation. Just as the sacrifices in Genesis and Judges allowed for and enabled the genesis and survival of a sacred community as well as the production and continuation of a sacred genealogy, the child killings and attempted killings in the Apophthegmata and monastic art result in a creation and continuation of a sacred monastic community, organized as much around ascetic mimesis, genealogical production, theological orthodoxy, and sacred authority as around familial renunciation.

Caroline T. Schroeder is Associate Professor of Religious and Classical Studies at the University of the Pacific in Stockton, California 